\title{
Developments Related to Tourism and Their Effects in Debrecen Following the Turn of the Millennium (Northern Great Plain Region, Hungary) Success Or Failure?
}

Mária Vasvári, Katalin Martonné Erdős, Richárd Molnár*

Received: Aprile 2013 | Accepted: May 2013

\begin{abstract}
The present paper focuses on the developments related to tourism and their effects in Debrecen, the largest city in the Northern Great Plain Region most of all in the time period after the country joining the European Union. The tourist industrial development regarding the infrastructure and suprastructure in Debrecen are presented. These developed further the traditionally popular attractions (Great Forest) of the city. Relationship between the demand and reception conditions are described reflecting statistic data and the role of Debrecen in the market is analysed in relation to several other greater towns of the country. Data reveal that the number of visitors did not increase despite the developments related to tourism in the years following the turn of the millennium, even so it decreased after 2008 similarly to other greater towns of the country.

Our questionnaire survey performed among the inhabitants and visitors as well revealed that the realized investments and the produced new attractions have only a slight role in attracting the target audience. Still the traditionally popular attractions attract most of the visitors to Debrecen therefore the most important task for the leaders of the Debrecen-Hortobágy Tourism Destination Management founded in 2010 is to propagate the new attraction elements.
\end{abstract}

Key words: Debrecen (Hungary), urban tourism, tourism developments, tourists' and local residents' attitude, development opportunities

\section{Introduction}

Towns are specific destinations. Their attractions are the most complex as numerous different type tourism products are present in a relatively small area (Michalkó, 1999). Apart from values and events preserving the heritage and culture of towns their high quality services

* Department of Landscape Protection and Environmental Geography University of Debrecen, Egyetem tér 1, 4032 Debrecen, Hungary; Corresponding author: vasvari.maria@science.unideb.hu 
are also important attraction elements. Advantageous traffic geographical location, central functions (economic, commercial, financial) of towns and relational, friendly connections towards their inhabitants also increase their tourism (Chadwick, 1987). Therefore visitors generally make use of more services than they planned although they visited the town with a firm goal - adventure, business, visiting family or friends, etc. - due to the diversity of attractions. A further advantage to other destinations is that the seasonality of tourism can be reduced significantly in towns by appropriate product development.

Second important distinctive characteristic of town destinations is that not only visitors utilize and visit the establishments, services and events of the tourism infrastructure but local inhabitants as well (Law, 2002; Juray, 2004; Juray, 2008; Edwards, Griffin, Hayllar, 2008). In this way, urban tourism and the increasing demand of urban population for recreation can become urban development factors strengthening each other (Aubert, 2008) and the investments targeting tourism and recreation as a result can generate significant changes in the economic and social life of towns. Apart from increasing tourism income new jobs are created, town scenery is changed and the life quality of local inhabitants is also changed, etc. (Michalkó, I999; Aubert, 200I).

Recognizing the increasing significance of urban tourism (European Commission 2OOO; WTO-ETC 2004; Sulyok, 2OO5) the European Union focuses more on promoting the tourism of towns and cities. One of the most well-known result of this is the "Cultural Capital of Europe" event series that provides opportunities for towns to show their cultural values year-after-year. The Community also provides various support opportunities for its member states to develop tourism.

Hungary was one of the most popular destinations of the socialist countries in the I980s. Although most of the tourists visited the capital the number of foreign tourists visiting the larger cities was not small either. Following the regime change, however, Hungary's competitiveness was much less compared to the more developed regions of Europe. Giving a new growth to tourism in Hungary was only possible with developments meeting higher tourism demands. In order to achieve this, the tourism development sub-programme of the Széchenyi Plan (200O-2004) was created. The results of this were numerous new tourism related investments with significant state support throughout the country including the development of tourism related attractions in the larger cities. Following the country joining the European Union in 2004 the sources of the European Regional Development Fund were also utilized.

In the present study the utilization and application of the new market possibilities following the regime change in Debrecen, in one of the most underprivileged statistic region, the Northern Great Plain Region of the country are analysed, bearing in mind that the city - based on its rich historical, cultural and religious heritage, medical water and commercial and catering trade supply regarded to be relatively good among socialist countries - was the most important tourism centre in the Great Hungarian Plain in the I970s and I980s.

\section{Methods and data}

In order to realize the above aims we reviewed the literature related to the research topic, used the datasets of the Central Statistics Office, the National Development Agency and other internet sources as well (http://palyazatok.org; http:/epulettar.hu/eszakalfold/, innova.eszakalfold.hu). In order to assess tourism demand and supply, questionnaire surveys 
were made. In order to obtain information on the social and demographic characteristics of tourists arriving into the city, on their travel motivations and opinion, demand, etc. regarding the tourism supply of the city, 339 visitors (3\% of the number of visitors registered at commercial accommodation) were questioned with random selection by the geographer students specializing in tourism of the Department of Landscape Protection and Environmental Geography, University of Debrecen between July 2OIO and December 2OII. Attitude to and knowledge about tourism of those hosting guests were analysed with the help of a survey made among the inhabitants (422 respondents, $0.2 \%$ of the inhabitants). Distribution of the respondents in relation to age and gender is presented in Figure I. The age group of I8-35 and Debrecen in relation to the distribution of respondents related to the permanent residence are slightly over-represented in both sets of questionnaires; however, this reflects the regional centre role of Debrecen in the Northern Great Plain Region. Considering education, $49 \%$ of the respondents have at least General Certificate of Secondary Education; ratio of those having higher education qualification is $30.8 \%$. As the majority of urban tourists have higher qualification the sample is appropriate for the research of the studied questions (Michalkó, 1999).

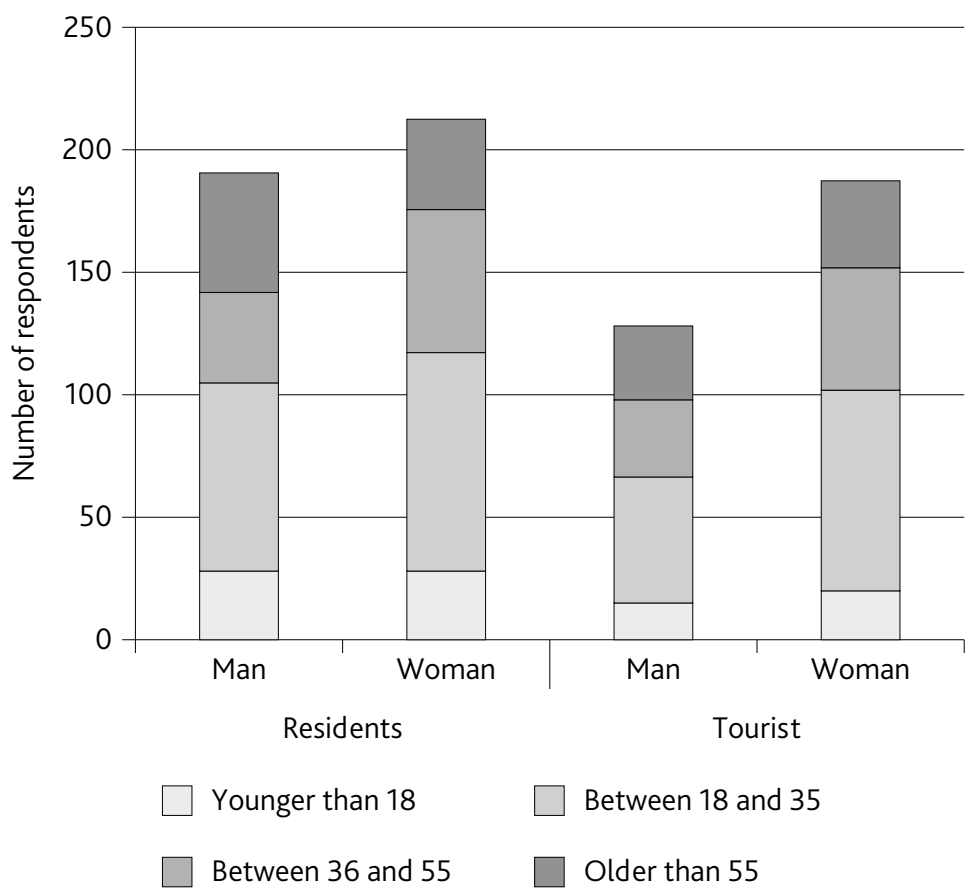

Figure 1. Gender and age of the respondents

Source: Own construction

In order to obtain more detailed information on the tourism policy and actual tasks of the city an interview with the tourism referent of Debrecen, furthermore, the representatives of the local Tourism Destination Management Association (TDMA), the Arany Bika Hotel (Gold Bull' Hotel) and the Central Statistics Office also answered our questions. 


\section{Developments}

Following the regime change tourist arrivals in Debrecen changed significantly. The almost four hundred thousand overnight stays characteristic for the first half of the I99Os decreased by one third and this process was especially rapid amongst foreign visitors (Martonné Erdős, 20O2). Although this disadvantageous trend seemed to be reversing by the middle of the decade it turned out that the effects of the market change of visiting tourists for Hungary were disadvantageous for Debrecen. Its attractions and supply were not competitive; visitors from the developed European countries did not compensate the decreasing number of visitors from the former socialist block. As a result the ratio of foreign overnight stay decreased from $63.6 \%$ in 1990 to $33.5 \%$ in 2000 . Although domestic tourism showed an increasing trend - with fluctuations though - after the lowest values in I99I, it could only partially counterweight the reducing foreign demand. In such conditions the renewal and quality extension of the offers for tourists of Debrecen became increasingly urgent in order to increase the number of both foreign and domestic visitors (Martonné Erdős, 2002).

For the realization of the above aims the first major step was the state support associated with the tourism development programme of the Széchenyi Plan (200O-2004) targeting the development of internationally competitive tourism products and the increase of service quality. The Debreceni Gyógyfürdő (Debrecen Spa) Ltd. won the tender in the framework of the "Medical and thermal tourism development sub-programme" resulting in the construction of the Aquaticum Debrecen, the pleasure bath of the city among the firsts in the country in 2003. Value of the investment creating 70 new jobs exceeded 2 billion forints (Table I) almost 50\% of which arrived in the city as support (Munduczó, Pulay, Tököli, 2OIO).

Following the country joining the European Union investments associated with the Regional Operative Programmes of the National Development Plan (2004-2006) and then

Table 1. Most significant tourism developments in Debrecen selected by the authors

\begin{tabular}{|c|c|c|c|}
\hline Name of realized investment & Support (Ft) & $\begin{array}{c}\text { Ratio of } \\
\text { support (\%) }\end{array}$ & Date \\
\hline Debrecen Airport development / phase I /EU- PHARE & 780000000 & 100 & 2001 \\
\hline Debrecen Aquaticum Mediterranean Pleasure Bath / Széchenyi Plan & 999000000 & 48 & 2003 \\
\hline Debrecen Congress Centre / Széchenyi Plan & 933000000 & 20 & 2006 \\
\hline New elegant hotel in the heart of Debrecen: Hotel Óbester & 211179721 & 30 & 2008 \\
\hline $\begin{array}{l}\text { New multi-functional exhibition rooms and visitor friendly developments } \\
\text { for the comfort of more visitors in the MODEM, Modern and Contempo- } \\
\text { rary Arts Centre }\end{array}$ & 224398800 & 90 & 2009 \\
\hline $\begin{array}{l}\text { Establishment of local TDMA in order to improve the tourism competi- } \\
\text { tiveness of Debrecen - Hortobágy }\end{array}$ & 63277064 & 85 & 2010 \\
\hline "Meeting of values" - Into the nature by the "ZSUZSI" Train & 400000000 & 90 & 2010 \\
\hline Development of the tourism services of the Kerekestelep Bath & 49890661 & 60 & 2011 \\
\hline Palace of Sciences & 163000000 & 85 & 2013 \\
\hline $\begin{array}{l}\text { Complex development of the Debrecen Spa (renovation of the outdoor } \\
\text { pool complex }+ \text { new hotel) }\end{array}$ & 475548851 & 50 & 2013 \\
\hline $\begin{array}{l}\text { Complex medical development in the park forest of the Great Forest in } \\
\text { Debrecen }\end{array}$ & 2104228580 & 100 & 2013 \\
\hline Hotel Arborétum Additional geothermal energy utilization, Debrecen & 229118693 & 51 & 2013 \\
\hline
\end{tabular}

Sources: palyazatok.org, epulettar.hu, innova.hu, nft.hu websites 
with the New Hungary Development Plan (2007-2OI3) were supported from Union sources. Several successful tenders are associated with the development of cultural and heritage tourism. Greatest of these is the rehabilitation of the historical city centre with function extension as well in the course of which the Memorial Garden, the Ruin Garden and the Red Tower behind the Great Church and the Halköz were renovated and became important public areas. In the framework of this project the first section of the western small boulevard was constructed easing the traffic pressure on the central parts of the city.

The local government has been planning the development of the Bath and Spa in the Great Forest for a long time that could be realized in this year as a result of a successful tender at the end of 2OI2. Apart from this, the service quality of the Kerekestelep Bath was improved with the help of European Union support (Table I) and the Szeged street Leisure Park was extended with a bath thanks to a private investment.

Large capacity commercial establishments are associated mostly with multi-national companies (METRO, TESCO, AUCHAN, Debrecen Plaza, FÓRUM).

Development of the infrastructure for traffic continued as well although in 2013 only inconvenience can be experienced from the construction of tram No. 2 by the visitors.

Support for tourism destination management organizations was planned both in the framework of the National Development Plan and the New Hungary Development Plan. Utilizing the tender possibilities based on these the local TDMA operating to improve the tourism competitiveness of Debrecen - Hortobágy was founded in 2010 (Table I).

\section{Changes in the leisure areas}

The above investments made the leisure areas of the city and its surroundings even more marked (Martonné Erdős, 20O2). The most important of these is the historical city centre. Most attractions are associated with this area and most of the establishments of the tourism infrastructure and suprastructure are located here. The majority of the tourism and city rehabilitation investments following the turn of the millennium were realized in the city centre as well improving further its cultural and other functions for public use (Figure 2) also improving the aesthetic attraction of the cityscape.

The other marked leisure area is the Great Forest Park with its immediate surroundings the tourism-recreation function of which has been extended continuously since the beginning of the $19^{\text {th }}$ century. This tendency has been continued with the investments of the last decade (bath development, hotel investments). Elements of tourism infrastructure and suprastructure occur scattered in other areas of the city mostly along the busy roads leading into the city.

The recreation zone surrounding Debrecen started to take shape in the area of the Erdőspuszták belonging to the Hajdúság Landscape Protection Area in the decades prior to the turn of the millennium. Inhabitants occupied quickly the park forests and lakes of the Erdőspuszták that have minimal infrastructure east of the city but the area remained practically unknown to visitors. A significant step forward was the opening of the first four-star hotel in the Erdőspuszták (Erdőspuszta Club Hotel, 2OIO) and the construction of a new hotel (Hotel Arborétum) has been started as well. The two medical and wellness hotels will be heated by thermal water in a project supported by the New Széchenyi Plan (Table I). 


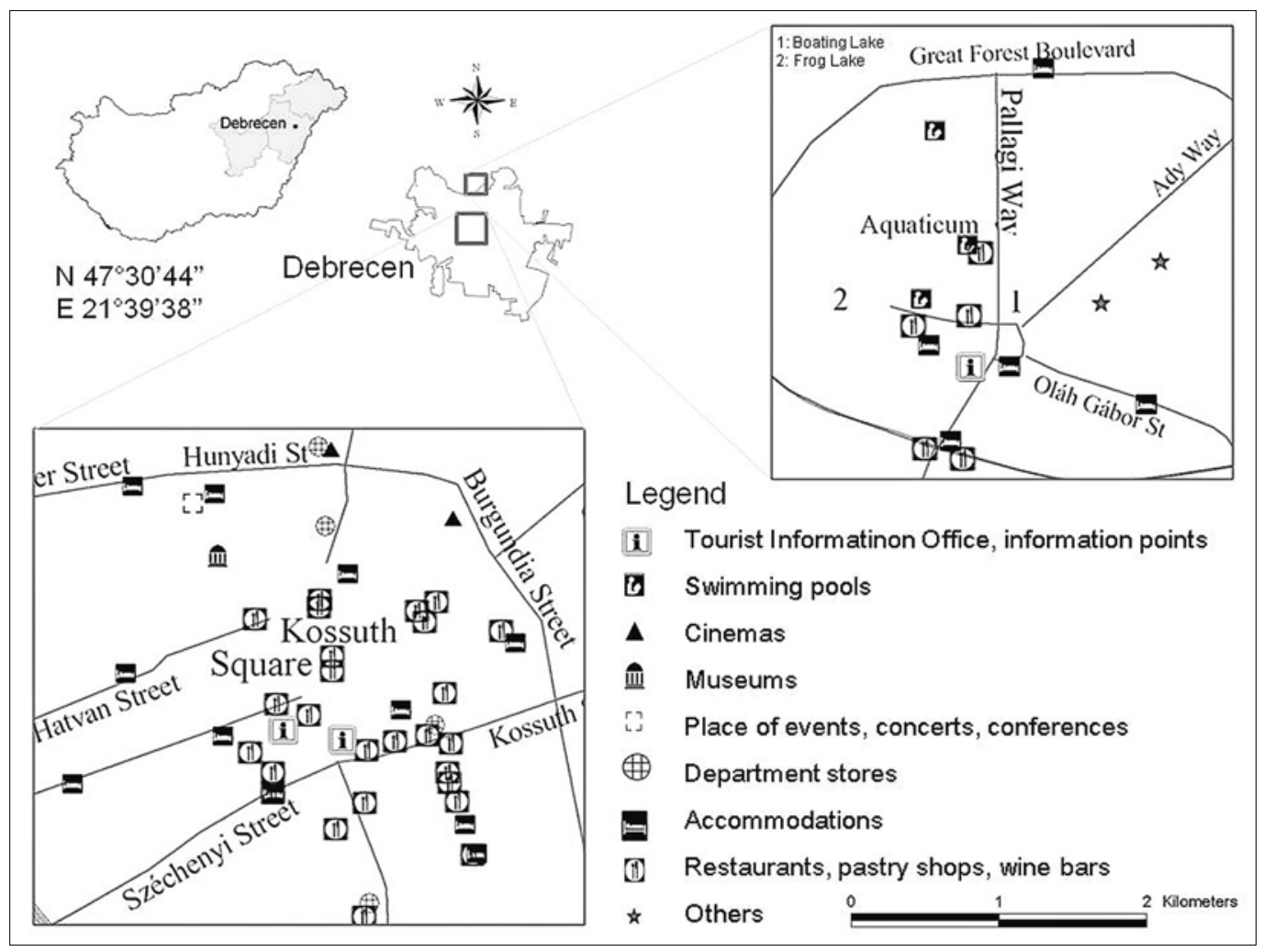

Figure 2. Tourism infrastructural and suprastructural establishments in Debrecen currently Source: Own construction

\section{Changes in the demand of visitors}

Considering the developments above, it is clear that the tourism offers of Debrecen are targeting complexity and quality services. Marked evidence for this is the change in the quality of accommodation (Figure 3). In the studied time period rooms of all accommodation types were decreasing - with fluctuations - except for hotel rooms. Their number was almost doubled by 2OIO; however, by $2 \mathrm{OII}$ a decrease of more than IOOO rooms was caused by the temporary closure of the Campus Hotel that operates as a student house in most of the year. The high decline of the number of pensions can be explained by the college is also rated to here in 2OIO. However, from $2 \mathrm{OII}$ the college rooms are categorized in the community accommodation. Growth is especially striking in the cases of four- and five-star hotel categories. The share of these two categories increased from I4.6\% at the end of 2000 to $56.7 \%$ by the end of $2 \mathrm{OII}$.

As a result of the developments, the number of tourist product types in the offer of the city was increasing. Hotel investments increased the range of health tourism products providing wellness, fitness and medical services and the number of hotels capable of hosting conferences.

Although events are concentrated in the week of the Flower Festival the city tries hard to attract visitors with a programme as rich in events as possible mostly in the summer but also in other periods of the year reducing somewhat the seasonality of tourism. Besides the events 


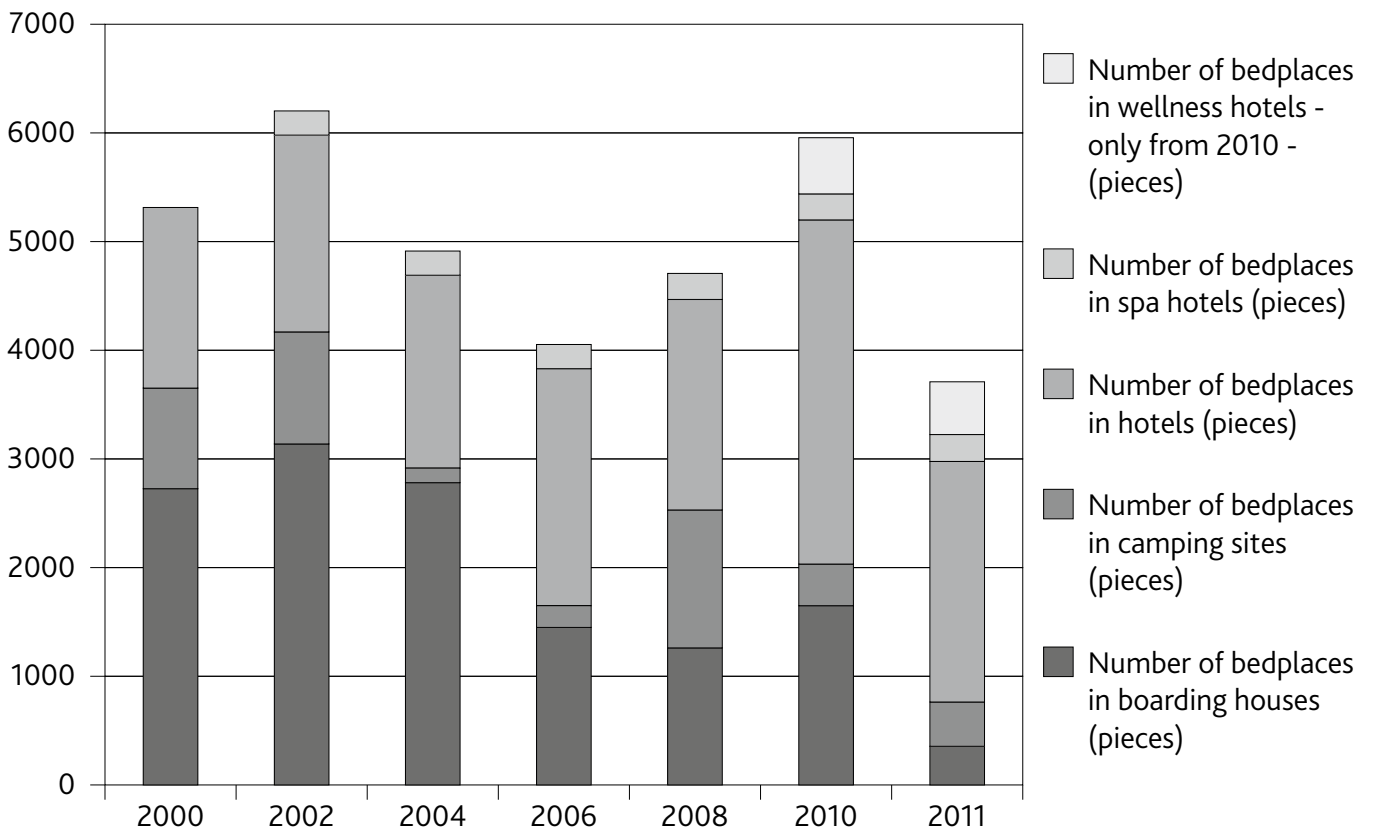

Figure 3. Changes in the number of rooms of commercial accommodation in Debrecen from 2000 till 2011.

Source: Prepared based on data from the CSO

of a long tradition several new cultural festivals, events and free time programmes have been organized recently. The swimming pool and the ice hall of the city - apart from serving the free time and competition sporting activity of the inhabitants - have already hosted several major international sport events. The multifunctional Főnix Hall became the place of several types of cultural and sport events. The Ruin Garden, the Halköz and the Baltazár square were also involved into the cultural and music life of the city. The Kossuth square and the Great Forest hold more-and-more music and gastronomic festivals, events apart from recreation (www.programturizmus.hu).

Marked improvements on the tourism offers side did not mean necessarily the increase of demand as the number of visitors was influenced not only by the effects of developments but the disadvantageous international and domestic economic processes as well. This explains the fluctuation of tourist arrivals. Regression with lowest numbers in 2004 was the result of economic growth in the European countries slower than average. Success of the developments is reflected by that the number of overnight stays and the number of visitors exceeded the values of 1990 first in 2006 and 2007 respectively. Since the outbreak of the financial and economic crisis in 2008 the tourist arrivals in Debrecen have been decreasing continuously (Figures 4 and 5). This resulted in a total loss of visitors and overnight stays of 36000 and I2O oOO respectively. Prolonged crisis is indicated by that the domestic arrivals - in contrast to the international - were decreasing even in $2 \mathrm{OII}$ as well. The share of foreign visitors from the turnover of commercial accommodations has been further reduced since the turn of the millennium.

In 2 OII the share of foreign overnight stays hardly exceeded 30\%. The trend was not reversed in the case of the average visiting time either, it decreased from 3.3 to 2.5 overnight stays. Visitors themselves are variable, however, the number of those staying in hotels increased by IO\% while the number of visitors staying in camping decreased significantly (www.ksh.hu). 


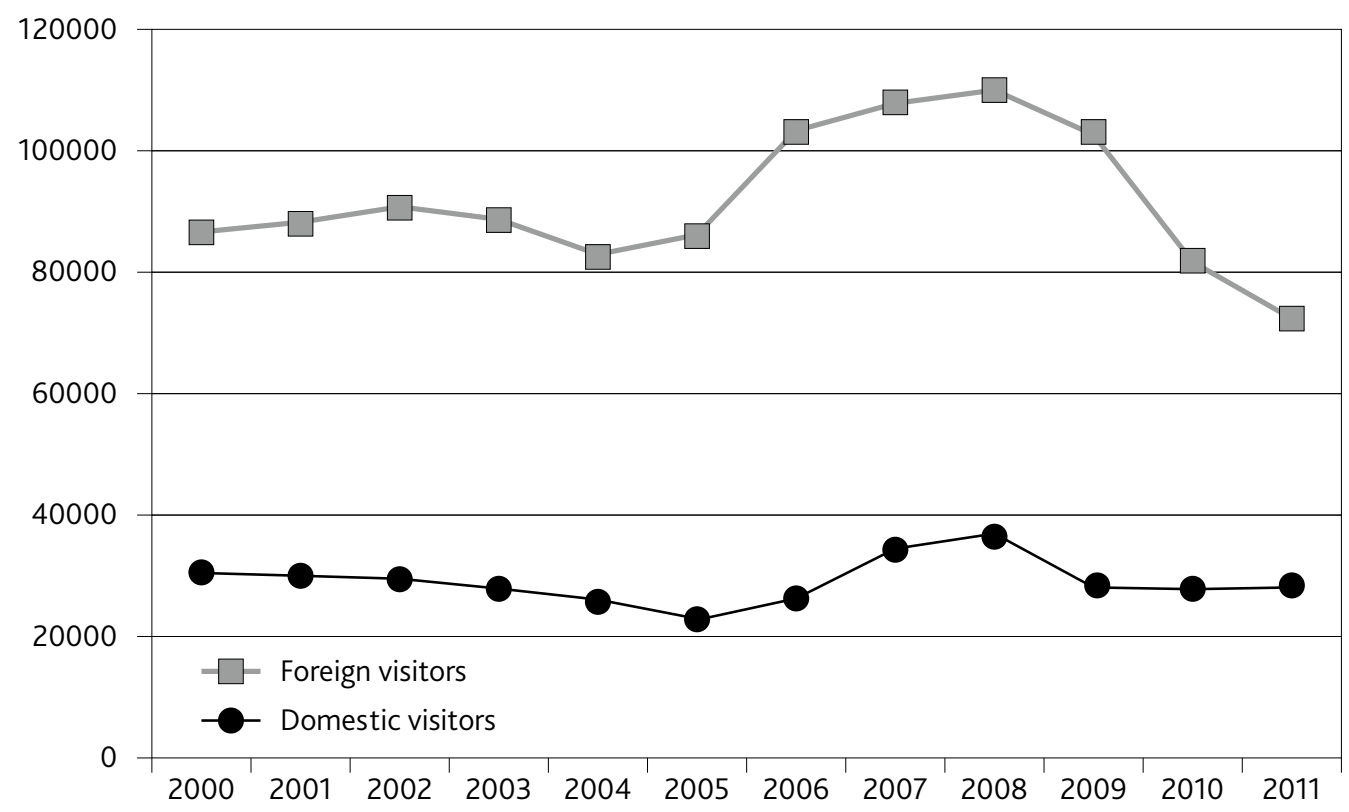

Figure 4. Number of foreign and domestic visitors in commercial accommodation (2000-2011) Source: Constructed based on data from the CSO

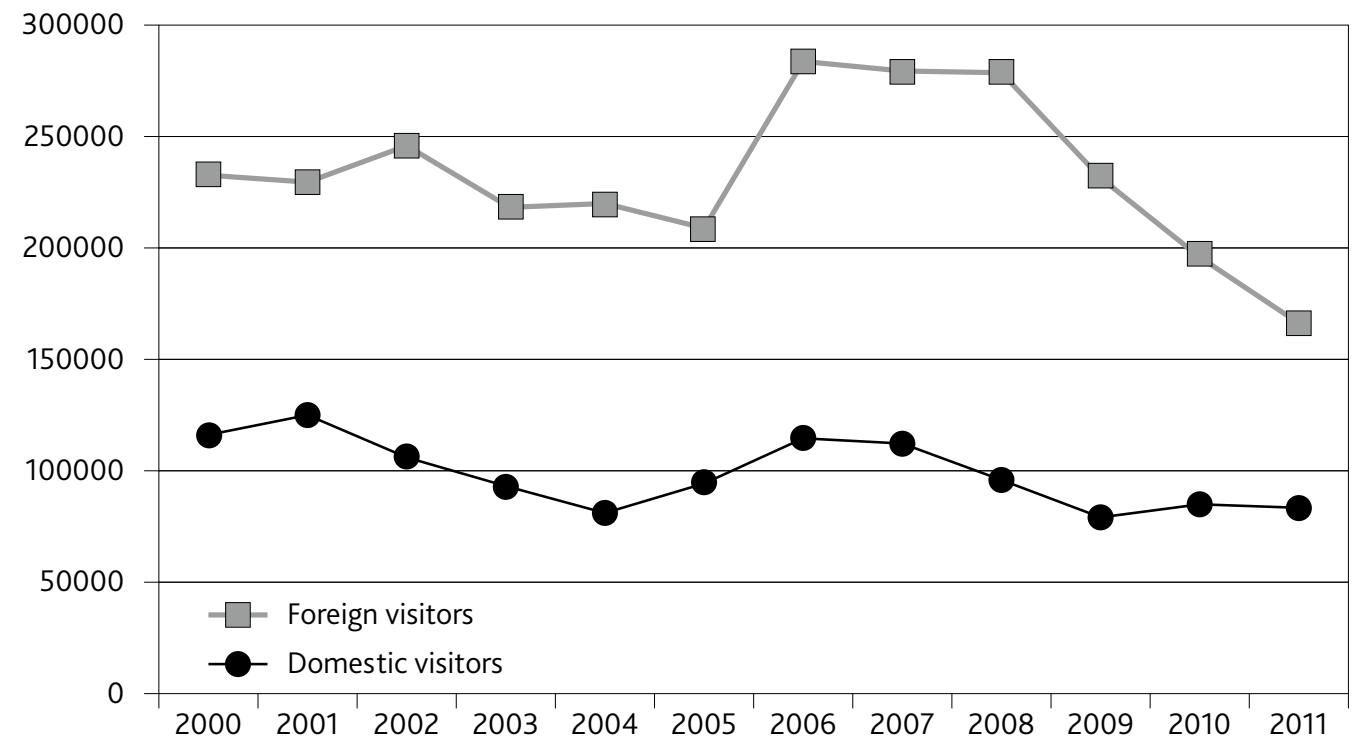

Figure 5. Number of foreign and domestic overnight stays in commercial accommodation (2000-2011) Source: Constructed based on data from the CSO

In conclusion it can be declared that the tourist arrivals in Debrecen were hit by the crisis. Success in preserving its position in the market can be assessed by a comparison with conditions in some larger towns with significant tourism. Figure 6 shows that Debrecen was clearly ahead of its rivals considering the number of overnight stays in the years before 


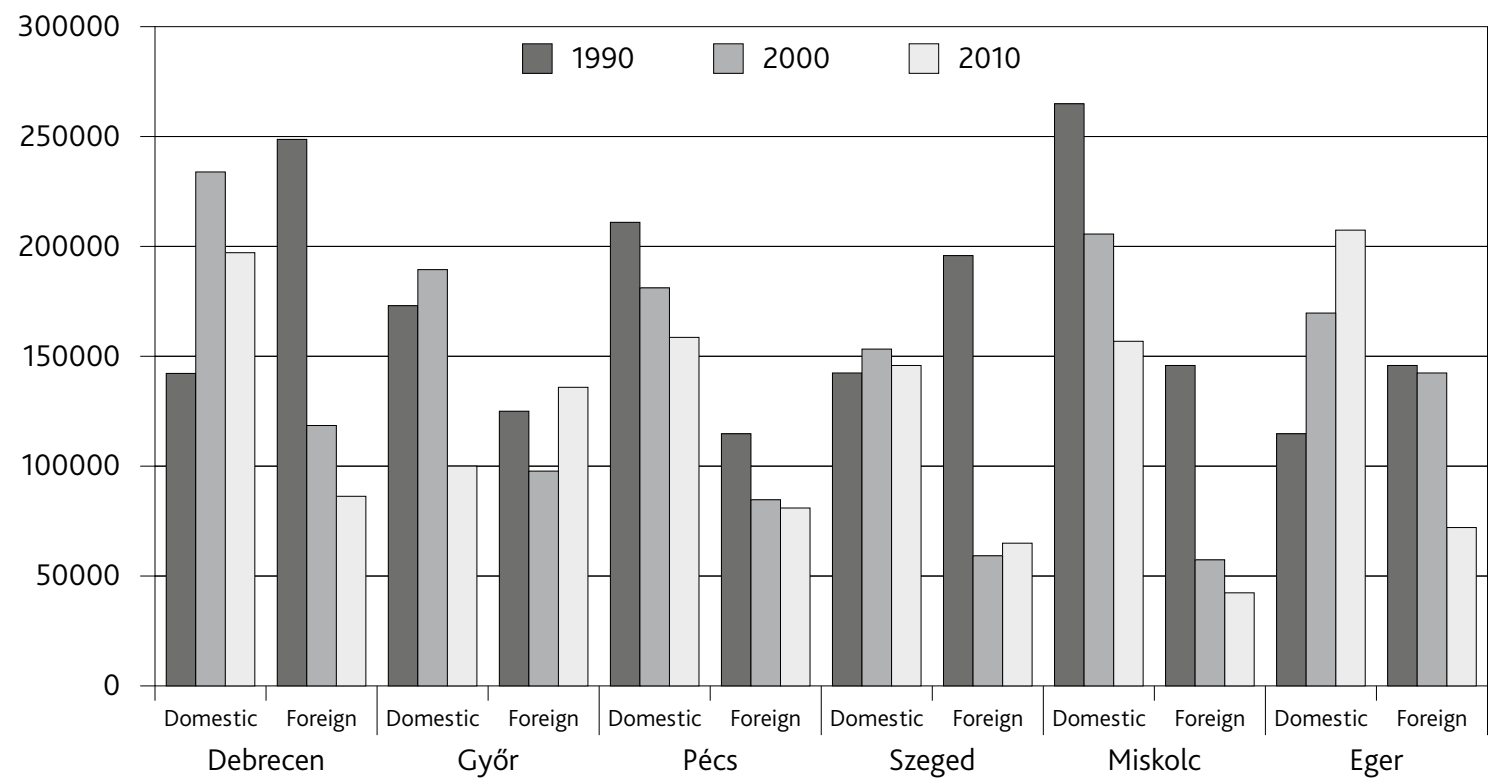

Figure 6. Position of Debrecen in the market regarding the number of overnight stays in commercial accommodation (1990-2000-2010)

Source: Constructed based on data from the CSO

the start of the crisis. By 2010 its tourist arrivals fell so much that it was overtaken by Eger. Exposing the reasons behind the increase in Győr and Szeged and analysing the poor data of Pécs in $2 \mathrm{OIO}$ despite being the cultural capital of Europe at that time would require another paper.

\section{Fields to be developed}

Development recommendations of inhabitants and visitors were taken into consideration in defining the future tasks. Comparing them with the development targets of the Tourism Development Strategy of the Northern Great Plain Region (2007-2OI3) and with those of the Development Strategy Programme between 2007 and 2013 of Debrecen Town of County Rank similarity is great.

Although significant efforts have been made in the interest of developing community areas, green areas tourists and inhabitants ranked the development of green areas suitable for recreation to first and second place respectively, even though the majority of them acknowledged the changes in the cityscape. This is why it would be important to place emphasis on increasing the tourism offers of the Erdőspuszták southeast of the city that could provide close-to-natural adventure for visitors. This area could also reduce the crowdedness of the city centre and the Great Forest in the high season. This idea harmonizes with the "tourist friendly environment" of the Tourism Development Strategy of the Northern Great Plain Region and the priorities of developing and protecting the natural and built environment declared by the city. This latter includes the rehabilitation of the city centre and the restructuring and development of the recreation grounds of the Great Forest and the Erdőspuszták.

Most of the inhabitants and many visitors thought the number of cultural events and programmes is not enough. It seems that despite cultural and heritage tourism develop- 


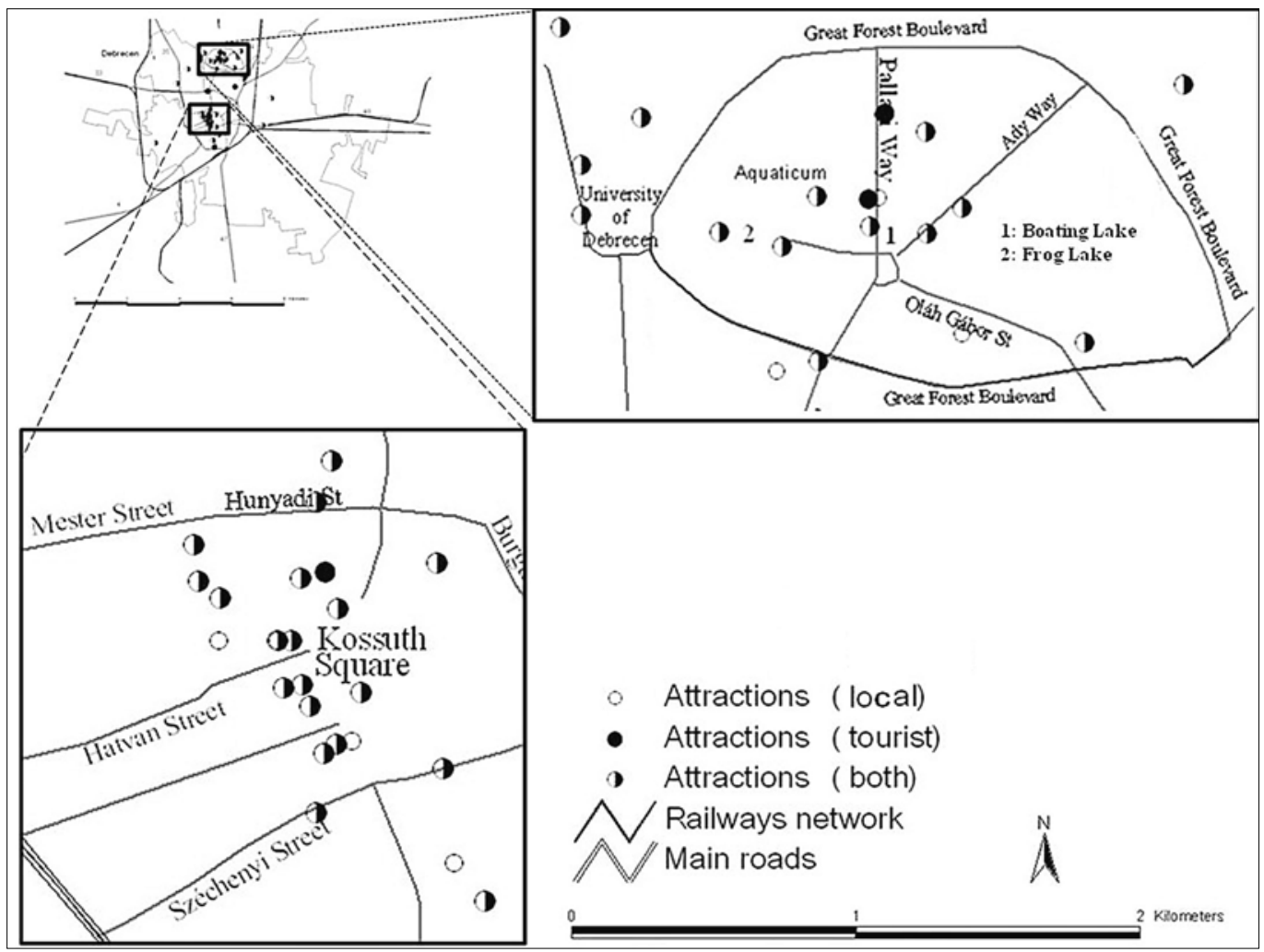

Figure 7. Locations of the visitor attractions in Debrecen and knowledge on them among local inhabitants and tourists

Source: own construction

ments realized in recent years and the number of events increasing year-by-year the image of the city reflecting poorly the historical-cultural heritage was not improved much (Rátz, 2008). Offers would be increased by the Scientific Adventure Park in the Botanic Gardens of Debrecen to be realized (planned in 2OI4) with European Union support. The main attraction element of the park will be the Palace of Sciences with educational, cultural and scientific functions (Table I). The renewing botanic garden would also offer an ecotourism programme in the city. Unfinished investment of the city centre is the Latinovits Theatre that would also extend the cultural offers.

Entertainment, wellness and active recreation were missed by visitors on the second place. Recognizing these, the Hotel Arborétum investment has been carried out in the Erdőspuszták, in the vicinity of Debrecen and this would provide medical, wellness, sport and other free time services apart from high quality accommodation from 20I3. It would be interesting to see how visitors and inhabitants know the current cultural, entertainment and sport possibilities in the city. According to our questionnaire survey the newer attractions produced by investments of the last decade are less known. The sights mentioned the most in the replies are the Great Church (2O,7\%), Great Forest (I2,I\%), University of Debrecen (6,5\%), Déri Museum (5,9\%), etc. and these have been the attractions of the city for decades. This means that the visitors filling the questionnaires arrive in the city due primarily to the tourism attractions with long history. 
Only the Aquaticum $(5,1 \%)$ and the Fórum $(2,4)$ appeared from the new attraction elements. This means that the colleagues of the TDMA have to apply a marketing strategy that advertises the new attractions. Visitors do not know and even local inhabitants do not regard the new establishments to be visitor attractions (Figure 7).

Both reply groups included open-air bath development as a strong demand. Development of health tourism is of special importance in the plans of both the Northern Great Plain Region and the city. Supply is improved only slightly by the investments in the Kerekestelep Bath and the Leisure Park at the Szeged street although wellness services associated with hotels were doubtless extended. The investment for the development of the Aquaticum Spa and Bathing Centre postponed for several times will bring quality changes much greater in volume than the ones before. The investment planned to be realized in the framework of the New Széchenyi Plan (2OII-2OI3) involves the extension of the thermal bath and wellness services and the construction of a new hotel with large capacity as well apart from the complete reconstruction of the open-air bath.

Improving hosting conditions includes the development of bicycle and public roads. This appears mainly among the replies of the locals but a part of the tourists regarded mass transport conditions as inauspicious experiences.

Qualification of hosting conditions can contribute to the definition of further development tasks. In our questionnaire survey visitors and inhabitants evaluated the conditions in a scale ranging one to five. Although average values $(3,5)$ show no great scatter they reflect the demand of improving the quality overall. Dissatisfaction related to events can be determined here as well and the situation is worse than average in relation to public hygiene $(3,4)$, public security $(3,5)$ and road conditions $(3,4)$.

Although only a few respondents noted the insufficient grade of marketing assessing their information sources influencing their travel decision it can be stated that around two third of the tourists selected Debrecen as their destination based on the earlier good experience of friends, relatives and their own. $\mathrm{I5.4} \%$ of the visitors obtained information on the Internet and only 4.I\% went into Tourinform offices for information on Debrecen. These low ratios reflect the current marketing deficiencies of the city despite the fact that the main aim of the Debrecen-Hortobágy TDM founded in 2010 was to improve this activity. According to the responses from the colleagues of the TDMA they achieved changes in the following fields after their foundation: modern facilities in the Tourinform office in Debrecen and Hortobágy. The GPS based city sightseeing system with voice guide was extended with new available in 3 languages - routes. Seven touch screen terminals have been installed in order to develop the visitor management system. The destination was advertised at 7 domestic travel exhibitions by the Association. Stand of the region received the "best attraction" prize in 2OII. On the basis of the replies, professionals are aware that the efficiency of marketing work has to be increased.

\section{Conclusions}

After the regime change, the tourist arrivals in Debrecen decreased significantly thus the extension and restructuring of the tourism offers of the city became an urgent task. Development programmes started from the turn of the millennium and related domestic and European Union support provided help for this. 
Several investments extending the tourism supply were realized in Debrecen as well most of which are related to the city centre and to the Great Forest, the traditional recreational area of the city strengthening further the attractions of these places (Figures 2 and 7). Developments improved the quality of offers the most striking feature of which is the increase in hotel accommodation (medical and wellness accommodation especially) (Figure 3). Product types were also increased especially in the fields of health, occupation, organization and gastronomy tourism. Extending tourism infrastructure and the rehabilitation of buildings and leisure time areas in the city centre serve the local community as well.

Effects of developments in increasing visitor number can be traced only till 2008. The crisis resulted in the significant decrease of visitor number especially in the case of foreign visitors (Figure 4).

In order to reverse the inauspicious trend several tasks have to be made by the city. Our questionnaire survey reveals that neither locals nor tourists know enough about the new attractions on offer in the city. Consequently one of the most important tasks of the Debrecen-Hortobágy TDM organization is to make new attractions more known. No sufficient results have been obtained yet in increasing the image of the city. Participating in national tourism exhibitions is not enough to attract more foreign visitors. Especially in the eastern part of the country greater attention should be paid to attract potential visitors from the countries of the former socialist block.

In order to strengthen the attractive force of Debrecen new elements have to be included in the offers. Besides cultural, heritage and medical tourism products, active tourism and wellness products could be increased based on the natural values in the surroundings of the city. With the development of the Erdőspuszták the temporary overcrowded state of the two traditional leisure time areas, the city centre and the Great Forest. On the other hand, it could fulfil the demand of tourists for "more green areas" and they may stay for longer time periods. Products could be made more colourful with the incorporation of the ecotourism attractions of the Hortobágy National Park in greater ratio than currently. The Debrecen-Hortobágy TDM is most suitable for the task.

Although the tender period between 2007 and 2013 of the European Union is closing utilizing further tender sources in developing tourism in the city is essential.

\section{Acknowledgement}

This paper was supported by the TÁMOP-4.2.2/B-IO/I-2OIO-OO24. The project is co-financed by the European Union and European Social Fund.

\section{References}

Aubert, A. (200I). A turizmus és a területfejlesztés stratégiai kapcsolata Magyarországon (Strategic connections of tourism and regional development in Hungary). Turizmus Bulletin 5/I, 44-49. (in Hungarian)

Aubert, A. (2008). Az urbanizációs folyamatok és a rekreációs életterek összefüggései Magyarországon (Relationship between urbanizing processes and recreational spaces in Hungary). In: Tájkutatás, Tájöklógia (Landscape research, Landscape ecology) (ed.: Csorba P., Fazekas I.) Meridián Foundation, Debrecen. 447-457. (in Hungarian) 
Chadwick, P. A. (1987). Concepts, definitions and measures used in travel research. In J.R. B. Ritchie and C. R. Goeldner (eds) Travel Tourism and Hospitality Research. A Handbook for Managers and Researchers, Wiley, New York, IOI-II6.

Az Észak-alföldi Régió Turizmusfejlesztési Stratégiája (2007-2OI3) (Tourism Development Strategy of the Northern Great Plain Region /2007-20I3/)

Edwards, D., Griffin, T., Hayllar, B. (2008). Urban Tourism Research: Developing an Agenda, Annals of Tourism Research 35(4), IO32-IO52.

European Commission (2000). Quality urban tourism, Integrated quality management (IQM) of urban tourist destinations, Brussels, I74.

Debrecen Megyei Jogú Város Fejlesztési Programja (2007-2OI3) (Development programme of Debrecen City of County Rank /2O07-2OI3/). http://portal.debrecen.hu/upload/File/ Gazdasag/koncepciok/varosfejlesztesiprogram2007_I3.pdf (download: 05/06/2OI2)

Juray, T. (2004). A városi turizmusfejlesztés és -tervezés kérdései a szegedi turisztikai koncepció készítésének kapcsán (Issues of urban tourism development and planning regarding the tourist concept of Szeged). in: Abonyiné, P. J., Komarek, L. (ed.): 4 O éves a Szegedi Tudományegyetem Társadalom- és Gazdaságföldrajz Tanszéke (Department of Social and Economic Geography of the University of Szeged is 40 years old), 89-99.

Juray, T. (2008). A város, mint turisztikai tér, Szeged példáján (City as a tourism area, on the example of Szeged). PhD theses. Szeged, I6. (in Hungarian)

Central Statistics Office (http://statinfo.ksh.hu/Statinfo/haViewer.jsp (download 22/O3/2OI2))

Law, M. C. (2OO2). Urban Tourism: The Visitors Economy and the Growth of Large Cities, London, 22I.

Martonné, E. K. (2OO2). Debrecen-Hajdúszoboszló-Hortobágy turizmusa a rendszerváltás után (Tourism of Debrecen-Hajdúszoboszló-Hortobágy after the regime change). Északelet-Magyarország, 7/3-4, I7-23. (in Hungarian)

Michalkó, G. (1999). A városi turizmus (Urban tourism). MTA FKI, Budapest, I68. (in Hungarian)

Mundruczó, Gy. , Pulay, Gy.,Tököli, L. (2OIO). A turisztikai fejlesztések állami támogatása térségi és nemzetgazdasági szintű hatékonyságának vizsgálata (State support and studying the effectiveness at national economic level of tourism developments). Research Institute of the National Audit Office, report. Budapest, (http://www.asz.hu/tanulmanyok/2OIO/a-turisztikai-fejlesztesek-allami-tamogatasa-tersegi-es-nemzetgazdasagi-szintu-hatekonysaganak-vizsgalata/t329.pdf; downloaded 29/05/2OI2) (in Hungarian)

Sulyok, J. (2005). Kulturális Turizmus az európai városokban (Cultural tourism in European cities). Turizmus Bulletin 3, I8-29. (in Hungarian)

Rátz, T. (2008). A magyar Athén és kálvinista Róma - kulturális üzenetek megjelenése a magyar városok észlelt imázsában (The Hungarian Athens and calvinist Rome - occurrence of cultural messages in the percieved image of Hungarian towns). Turizmus Bulletin I2/3, 4I-5I. (in Hungarian)

World Tourism Organization, European Travel Commision (2004). City Tourism and Culture - The European Experience.

http://www.programturizmus.hu/tdestination-fesztival-kultura-gasztronomia-program-rendezveny-debrecen.html

http://palyazatok.org

http://epulettar.hu/Search/?t=kb\&mq=Debrecen

http://innova.eszakalfold.hu 